\title{
An Empirical Study on the Dynamic Relationship between Crude Oil Prices and Pakistan Stock Market
}

Rabia Najaf* and Khakan Najaf

Department of Accounting and Finance, University of Lahore, Islamabad Campus, Pakistan

\begin{abstract}
The purpose of this paper to analysis the impact of crude oil on the stock exchange of Pakistan. For this purpose, we have taken the data feom 15 years and applied the Karl Pearson's Coefficient of Correlation and taken the results that decrease the value of crude oil have negative impact on the stock exchange of Pakistan. This paper is trying to show that in all over the world oil is known as the more crucial source of energy. Oil prices are known as the biggest need of every country due to this reason prices brings effect on the performance of the country. Now the days the prices of oil as important as the gold prices. The world largest commodity market is known as the crude market. Our paper is also showing that increase in the prices of crude oil is the reason of inflation.
\end{abstract}

Keywords: Inflation rate; Pearson's coefficient; Commodity; Crude oil; Crude market

\section{Introduction}

In all over the world oil is known as the more crucial source of energy. Oil prices are known as the biggest need of every country due to this reason prices brings effect on the performance of the country. Now the days the prices of oil as important as the gold prices. The world largest commodity market is known as the crude market. Different scholars proved that crude oil impact on the economy of the countries. Oil prices have also impacted on the consumption and production of commodity. Shortages of crude oil prices affect the markets of emerging countries. From 2008 the emerging markets are facing the problem of crisis of oil. Due to these crises more and more turn their eyes to the emerging markets. In the era of 1990s the prices of oil were between $\$ 19$ and $24 \$$. On the other hand, at the middle of 2007 , it has reached till $70 \$$. These prices are impact $t$ on the economy of Pakistan, china and India. These shocks also effect on the prices of petroleum. However, all these shocks impact on the stock market capitalization. Oil importing countries lead to inflation due to crisis of oil prices. More ever, oil price risk is being effected on the financial market. From last decades, it is seen that it is very burning question that impact of oil prices on the emerging stock exchange. Most of the researches are made to found out the impact of oil prices on these stock exchanges. In this paper, we are trying to find out the impact of oil prices on the stock exchange of Pakistan (Table 1 and Figure 1).

\begin{tabular}{|c|c|c|}
\hline Month & Price & Change \\
\hline Jul 2015 & $5,538.82$ & - \\
\hline Aug 2015 & $4,685.18$ & $-15.55 \%$ \\
\hline Sep 2015 & $4,832.01$ & $3.23 \%$ \\
\hline Oct 2015 & $4,913.54$ & $1.79 \%$ \\
\hline Nov 2015 & $4,551.36$ & $-7.47 \%$ \\
\hline Dec 2015 & $3,832.17$ & $-15.91 \%$ \\
\hline Jan 2016 & $3,138.66$ & $-18.15 \%$ \\
\hline Feb 2016 & $3,252.59$ & $3.67 \%$ \\
\hline Mar 2016 & $3,912.00$ & $20.38 \%$ \\
\hline Apr 2016 & $4,269.99$ & $9.25 \%$ \\
\hline May 2016 & $4,818.24$ & $12.94 \%$ \\
\hline Jun 2016 & $4,993.27$ & $3.73 \%$ \\
\hline Jul 2016 & $4,637.61$ & $-7.22 \%$ \\
\hline
\end{tabular}

Table 1: Oil prices in Pakistan.

\section{Problem Statement}

Impact of crude oil prices on the stock exchange of Pakistan.

\section{Objectives}

1) Impact of increase in crude oil on the prices of Pakistan.

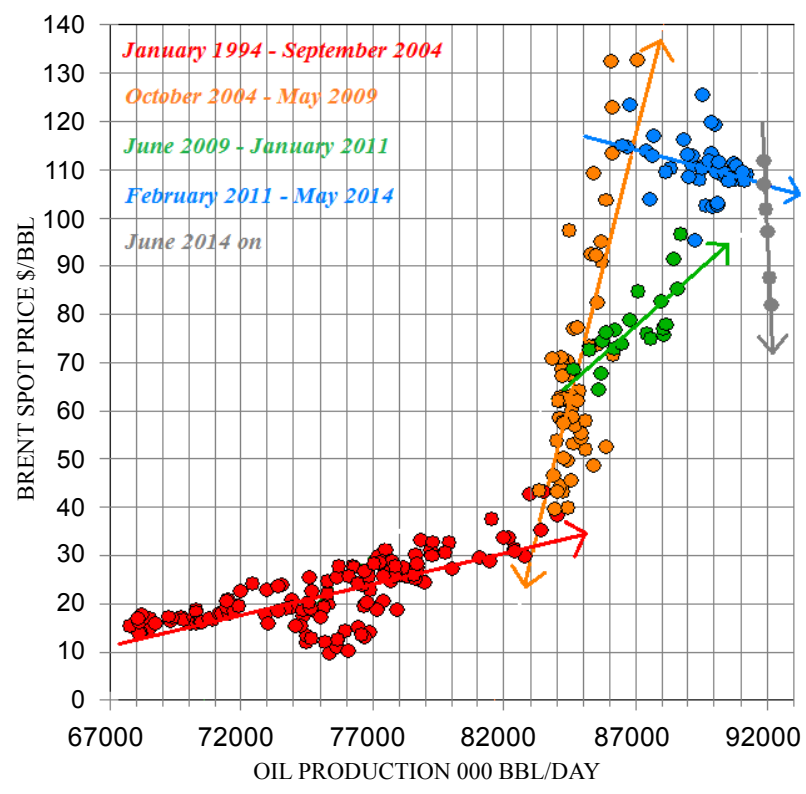

Figure 1: Brent spot prices.

*Corresponding author: Rabia Najaf, Department of Accounting and Finance, University of Lahore, Islamabad Campus, Pakistan, Tel: +92 (0)42 111-865-865; E-mail: rabianajaf@hotmail.com

Received September 06, 2016; Accepted September 22, 2016; Published September 29, 2016

Citation: Najaf R, Najaf K (2016) An Empirical Study on the Dynamic Relationship between Crude Oil Prices and Pakistan Stock Market. J Account Mark 5: 194 doi:10.4172/2168-9601.1000194

Copyright: ( 2016 Najaf $R$, et al. This is an open-access article distributed under the terms of the Creative Commons Attribution License, which permits unrestricted use, distribution, and reproduction in any medium, provided the original author and source are credited. 
2) Decrease of oil prices on the stock price of Pakistan.

3) There is long run relationship between crude oil and stock exchange of Pakistan.

4) There is short run relationship between crude oil and stock market of Pakistan.

\section{Literature Review}

Chad Langager found that there is negative relationship between oil prices and stock exchange of USA. For this purpose, they have utilized the data from 1998 to 2009 and applied the VAR model. Results have shown that there is long run relationship between oil prices and stock exchange [1].

Kothari analyzed that there is negative relationship between oil prices and stock exchange of Germany. For this purpose, they have utilized the data from 1999 to 2010 and applied the VECM model. Results have shown that there is short run relationship between oil prices and stock exchange $[2,3]$.

Kumar observed that there is negative relationship between oil prices and stock exchange of UK. For this purpose, they have utilized the data from 1990 to 2010 and applied the multi regression model. Results have shown that there is long run relationship between oil prices and stock exchange [3].

Anandan showed that there is negative relationship between oil prices and stock exchange of Finland. For this purpose, they have utilized the data from 1991 to 2011 and applied the unit root test. Results have shown that there is long run relationship between oil prices and stock exchange [4].

Panandiker found that there is negative relationship between oil prices and stock exchange of Itlay. For this purpose, they have utilized the data from 1992 to 2008 and applied the VECM model. Results have shown that there is short run relationship between oil prices and stock exchange [5].

Rajan analyzed that there is negative relationship between oil prices and stock exchange of France. For this purpose, they have utilized the data from 1995 to 2000 and applied the classical regression model. Results have shown that there is short run relationship between oil prices and stock exchange [6].

RBI, Showed that there is negative relationship between oil prices and stock exchange of Tehran. For this purpose, they have utilized the data from 1991 to 2011 and applied the Granger-causality test and vector autoregressive (VAR) model. Results have shown that there is long run relationship between oil prices and stock exchange [7].

Capie, Mills and Wood analyzed that there is negative relationship between oil prices and stock exchange of Nigeria. For this purpose, they have utilized the data from 1995 to 2000 and applied the Augmented Dickey Fuller Unit Root Test, Johansen co-integration test model. Results have shown that there is short run relationship between oil prices and stock exchange [8].

Dickey and Fuller observed that there is negative relationship between oil prices and stock exchange of Japan. For this purpose, they have utilized the data from 1990 to 2010 and applied the Johansen co-integration test and vector error correction model. Results have shown that there is long run relationship between oil prices and stock exchange [9].

Wang and Yuan-Ming Lee found that there is negative relationship between oil prices and stock exchange of Iran. For this purpose, they have utilized the data from 1992 to 2008 and applied the Co-integration and Vector Error Correction Method (VECM). Results have shown that there is short run relationship between oil prices and stock exchange [10,11].

\section{Gape in the literature}

1) In the prior study nobody had discussed about the increase crude oil on the inflation.

2) In the last studies there is not proper discussion about crude oil on the monetary policy of all the countries.

3) In the last few decades, nobody discussed about crude oil prices on the economy of the country.

\section{Methodology}

Our paper is showing that with the numerous ways our economy is affected by the crude oil. There is unqualified statement is that the decrease in the prices of crude oil is become the reason of boon for Pakistan. It is seen that monetary policy is based on the inflation rate. This paper is also helpful to quantify the impact of crude oil price on the economy of Pakistan. We have applied the Karl Pearson's Coefficient of Correlation for proper analysis. Further, Linear regression has been used to forecast the future cause and effect relationship between crude oil price and inflation and the linear regression is given by:- [3]

$(\mathrm{Y})_{\mathrm{i}}=\mathrm{a}+\mathrm{b}(\mathrm{X}) \mathrm{I}+($ error)i Where; -

$(\mathrm{Y})_{\mathrm{i}}=$ value of average inflation for year,

$a=$ mean value of inflation ( $i=$ intercept coefficient),

$\mathrm{b}=$ average change in inflation when one unit change in crude oil price (slope of crude oil price),

(X)i=value of crude oil price for year (Tables 2-5).

\section{Results}

In the Tables 1 and 2 the regression analysis is indicating the average value of crude oil and inflations from the last 15 years. In the Table 3 derived the correlation between inflation and crude oil prices.

$\mathrm{a}=2.45304358$ (Intercept coefficient),

$b=0.07134506$ (coefficient of value of crude oil price)

Regression equation is thus given by;-

\begin{tabular}{|c|c|c|}
\hline Year & Average Crude oil price USD & Average Inflation CPI \\
\hline $2 \mathrm{k}-2001$ & 26.3 & 3.78 \\
\hline $2002-03$ & 21.8 & 4.32 \\
\hline $2003-04$ & 26.8 & 3.82 \\
\hline $2004-05$ & 28.3 & 3.78 \\
\hline $2005-06$ & 40.3 & 4.26 \\
\hline $2006-07$ & 55.4 & 5.78 \\
\hline $2007-08$ & 61.9 & 6.38 \\
\hline $2008-09$ & 79.4 & 8.33 \\
\hline $2009-10$ & 83.7 & 10.84 \\
\hline $2010-11$ & 69.9 & 12.12 \\
\hline $2011-12$ & 85.2 & 8.88 \\
\hline $2012-13$ & 111.8 & 9.4 \\
\hline $2013-14$ & 109 & 10.93 \\
\hline $2014-15$ & 105.6 & 6.38 \\
\hline
\end{tabular}

Table 2: Average value of crude oil and inflations from the last 15 years. 
Citation: Najaf R, Najaf K (2016) An Empirical Study on the Dynamic Relationship between Crude Oil Prices and Pakistan Stock Market. J Account Mark 5: 194. doi:10.4172/2168-9601.1000194

Page 3 of 3

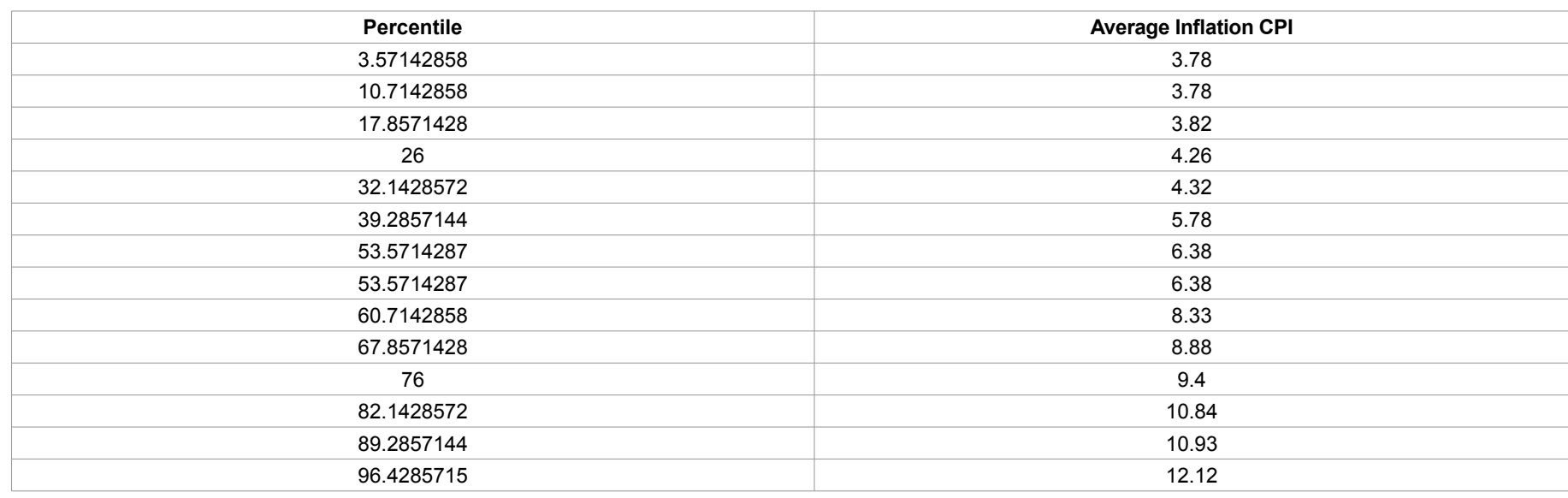

Table 3: correlation between inflation and crude oil prices.

\begin{tabular}{|c|c|c|}
\hline & \multicolumn{2}{|c|}{ Average Crude Oil Price USD } \\
\hline Average Crude Oil Price & 2 & 0.775699 \\
\hline Inflation CPI & 2 \\
\hline
\end{tabular}

Table 4: Correlation.

\begin{tabular}{|c|c|c|c|c|c|c|c|c|}
\hline df ss & MS & & & & & & & \\
\hline Regression & $\mathrm{F}$ & Significance F & & & & & & \\
\hline Residual & 1 & 69.01808 & 69.01809 & 18.12873 & 0.001113 & & & \\
\hline \multirow[t]{2}{*}{ Total } & 12 & 45.68535 & 3.807114 & & & & & \\
\hline & 13 & 114.7034 & & & & & & \\
\hline Intercept & Coefficients Std Error & & t Stat & $\mathrm{P}$-value & Lower & Upper & Lower & Upper \\
\hline Average & 2.4530436 & 1.2006621 & 2.043077 & 0.063646 & -0.16298 & 5.06907 & -0.16298 & 5.06907 \\
\hline Crude oil & 0.0713451 & 0.0167563 & 4.257785 & 0.001113 & 0.03485 & 0.10786 & 0.034837 & 0.10786 \\
\hline price USD & & & & & & & & \\
\hline
\end{tabular}

Table 5: ANOVA.

\section{$\mathrm{Y}=2.4531+0.0732(\mathrm{X})$ where;}

$\mathrm{Y}$ is inflation and $\mathrm{X}$ is the crude oil price.

Adjusted R square $=0.5686$ which measures the fit implying that $56.86 \%$ of inflation is determined by the crude oil price.

This result is showing that there has been $77.7 \%$ correlation between crude oil and inflation.

\section{Conclusion}

In Pakistan, central bank and government both deal the inflation rate. Our study is showing that Crude oil has crucial role in the development of the economy. Further, the trends are showing that Crude oil has also impact on the prices of commodity. Monetary policy has effected on the Investment decision. Our study is showing that inflation rate depend upon the increase and decrease the crude oil. Crude oil enhances the development of the country.

\section{Recommendations}

1) In Pakistan, there is proper need of infrastructure about the policy of crude oil.

2) For the development of the economy, there is need of proper organized policy.

3) Government should make uncertain programmers in the condition of oil crisis.

\section{References}

1. Langager $C$ (2015) What is the relationship between oil prices and inflation Investopedia.com.

2. Inflation (2014) Inflation - current and historic inflation by country.

3. Kothari CR (2011) Research methodology: methods and techniques. (2ndedn) Delhi, New Age International.

4. Kumar A (2015) How falling crude prices impact India's GDP, inflation. Zee News, India. Mumbai.

5. Anandan M, Ramaswamy S, Sridhar S (2013) Crude Oil Price Behaviour and Its Impact on Macroeconomic Variable. Language in India 13:147-161.

6. Money Control Bureau (2014) Money Control. moneycontrol. Com.

7. Money Control Bureau. (2014). Money Control. Retrieved Sep 20, 2015, from Weakness in crude price augurs well for India, which imports about 70 percent of its petroleum requirement, and results "in lower inflation, improvement in fiscal and current account balances and higher growth," a recent note by brokerage firm Nomura said.

8. OECD (2011) The effect of Oil Price Hikes on Economic Activity and Inflation OECD Economics Dept Policy notes, No 4.

9. Panandiker DH (2015) Thompson Reuters, blogs.reuters.com. Mumbai.

10. RBI (2014) Crude price slump a boon for India, says RBI.

11. World Bank (2015) Global Economic Prospects. Global Economic Prospects. 